\title{
The Promise of Sociology: Global Challenges for National Disciplines
}

\section{Michael Burawoy}

University of California, Berkeley, USA

\begin{abstract}
Sociology was founded as a positivist and universal science that obscured its national parameters. A first response was to attack false universalism with the particularism of indigenous sociologies, but this effectively reproduced the domination of northern sociologies. A second response has been to recognize and trace the superimposition of national traditions in a hierarchical world. With the movement toward commodification and rationalization of knowledge production, however, national sociologies have been aligned with and merged into the global field of sociology. Opting out of this field leaves one in the wilderness, so the third response is to enter struggle on the terrain of this global field, which in turn requires accountability to publics. To be sure there are limits to these struggles, but they are nonetheless important in keeping sociology alive as a distinct discipline, that is keeping alive the critical standpoint of civil society against the overextension of the market and its accomplice the regulatory state.
\end{abstract}

\section{Keywords}

civil society, globalization, sociology, universalism

Founded as a science akin to chemistry and physics, the early positivists - Comte, Spencer, Durkheim - thought of sociology as offering universal knowledge, independent of its mode of production or place of application. This assumption of context-free knowledge was an illusion, but a necessary illusion that propelled sociology's development, while defending it in hostile environments.

Sociology's universalistic claims were strongest in its Golden Era after the Second World War. This was the era of modernization theory and structural functionalism - a messianic science emanating from elite universities in the USA that spread over the

\footnotetext{
Corresponding author:

Michael Burawoy, Department of Sociology, University of California, Berkeley, CA 94720, USA.

Email: burawoy@berkeley.edu
} 
globe. US elites, glowing with victory over Fascism in the Second World War, saw themselves at the head of the 'lead society', a model to be emulated by all. Reflecting this self-congratulatory vision and division of the world, US sociology was further galvanized by the Cold War, presenting itself as a true science against Marxist ideology.

With the end of the Cold War sociology had to find a new raison d'etre. After a period of crisis and challenge from within, US sociology managed to resuscitate itself with an infusion of social engagement that has given new impetus to its scientific exploits. Without abandoning public engagement, sociology's challenge today is to go global. It can no longer be confined to a national container; it has to wrestle with the realities of global conflict and global inequality as they shape both its object of analysis and its practice as a science.

\section{From Universalism to Particularism}

The present era of US sociology began with the burgeoning social movements of the 1960s that called into question the messianic self-representation of the USA as a harmonious, democratic order. Critical sociologies took mainstream sociology to task even as they themselves laid claim to the mantle of an alternative universality, continuing to be blind to the national context from within which they emanated. To this day many US sociologists remain staunch believers in a positivist universalistic social science, unreflective of the national parameters of their research and thinking. The proliferation of comparative studies has made some dent on US sociology's pretensions to universality, made it more conscious of the peculiarities of its object, but even then the conception of the USA has usually provided the unquestioned reference point for evaluating other countries on such scales as democracy, corruption, civic culture, values, and so on.

Not surprisingly, this false universalism has been challenged from subjugated places that question the generality of its claims. Feminists and critical race theorists have radically questioned the universality of much conventional sociology - claims that more properly pertain to men rather than women, white rather than black, straight rather than gay. But dominated nations have also been fertile soil for challenges to universalistic theories. So in the 1970s and the 1980s we discover the spread of indigenous sociologies in India, Africa, and Latin America. In other words, advancing universalism, gave rise to its opposite, particularism. With limited appeal it has not been an effective challenge to the hegemony of western sociology, given all the resources at its command. A more open and conciliatory response to the heavy weight of western sociology explores diverse sociological traditions in different parts of the world (Genov, 1989; Patel, 2010). But, as Gurminder Bhambra (2014) insists, such diverse sociologies have to be seen in their connection, not as independent strands of theory.

More direct challenges to western sociology came from those imbued with a postcolonial disposition that 'coloniality' (Quijano, 2000) continues to organize global inequality. Subaltern studies, originally associated with Indian social scientists such as Dipesh Chakrabarty (2000), Partha Chatterjee (1986), and Ranajit Guha (1983), started out from the notion that national independence had not delivered on its promises - promises saturated with the ideas of western democracy and market society that have conventionally underpinned western sociology. Indeed, aspirations to bourgeois society are shown not 
only to be infeasible but they led to a deepening of national subjugation. Frantz Fanon (1963 [1961]), the original postcolonial theorist, understood this with extraordinary lucidity even before history made it self-evident: he demonstrated that the conditions for capitalist accumulation, liberal democracy, and civil society as they are known in advanced capitalism were simply absent in the postcolony. The National Bourgeois road, as he called it, was doomed to end in a miasma of political dictatorship and internecine warfare. The only promising road forward, he argued, was a National Liberation struggle. But this has proven to be no less elusive. The wreckage left behind demands an alternative sociology, but what that might be is still not clear.

Raewyn Connell's Southern Theory (2007) takes an important step in that direction. She offers a sweeping indictment of northern sociology, epitomized by the implicit and unreflected universalism found in the works of James Coleman, Anthony Giddens, and Pierre Bourdieu - a universalism once again at odds with the realities of the Global South. Countering northern supremacy, Connell offers a rich menu of social theory from the South - a range of theorists that have been overlooked by the canonical works of the North. This reductionist dichotomy of northern and southern sociology rides roughshod over different national traditions in the North (German, French, Anglo-Saxon, US, etc.) as well as the national traditions to which southern sociologists themselves belong. Whether it be South Africa's Solomon Plaatje or Argentina's Raul Prebisch or Iran's Ali Shariati, these theorists belong neither to the South or North, having sprung from national intellectual fields but shaped in reaction to or through assimilation of northern theory. Southern theory produces a false dichotomy, a false homogenization that expels social theory from its political and economic contexts - national and imperial - that give it meaning. These theorists are known to Connell because of their cosmopolitan reach, they speak from the South because they are deeply entangled with the North.

If we are going to talk about an autonomous southern theory, then we would do better following Jean and John Comaroff's Theory from the South (2012) that starts from the distinctive social processes and historical legacies that can be found in Africa and elsewhere - processes that are now spreading, they claim, to the North. Or as Jan Breman (2013) has said, the 'Rest' is no longer following in the footsteps of the West but leading the West in a downward spiral of economic involution. The global field of social theory cannot be divorced from the material and political conditions from which it emanates. Particularistic responses to false universalism land social theory, sociology, in the same cul-de-sac they claim to escape.

\section{National Traditions in a Hegemonic Order}

There is a global field of sociology and so slicing off 'alternative' discourses, be they called indigenous sociology or southern theory, is no more viable then laying claim to a singular, universal sociology (Sztompka, 2011). The advocacy of a universal sociology continues to be a hegemonic strategy of the dominant, propagated by interested collaborators across the world, generating a 'counterhegemonic' strategy of a plurality of particularistic sociologies. Both sides are misguided since the contest is not a warring of the holy and the unholy but takes place in a field of hierarchically interconnected sociologies. 
From the beginning sociology was implicated in an imperial project in the very way it formulated the relation between metropolis and periphery as a relation between civilization and exotic otherness, advanced and backward societies. Whether it be Spencer's 'industrial society' or Durkheim's 'organic solidarity', each provides an ideology of distinction, the superiority of modernity over tradition, based on evolution and differentiation. With the notable exception of WEB Du Bois, early US sociology largely imitated or elaborated on the Europeans. The advance of hegemony is not simply how northern sociological traditions conceive of the superiority of their societies, but also how those traditions attracted and cultivated committed emissaries who carried them into the colonial hinterland.

Thus, Indian sociology is still influenced by British social anthropology and US cultural anthropology. Dominated by the redoubtable figure of MN Srinivas, Indian anthropology and sociology focused on rural communities and the significance of caste. We can say that in India anthropology dominated sociology, a reflection of a parallel situation in Britain where sociology always had weak roots and really only took off with the expansion of the new universities in the 1960s. Its prehistory was dominated, on the one hand, by the study of social administration tied to the rise of the welfare state and, on the other hand, by social anthropology, tied to Britain's Imperial role.

South African sociology, also influenced by British social anthropology, today sports the strongest autonomous sociology in Africa. South African sociology began as an apology for apartheid, but in the 1970s it was displaced by an engaged scholarship ever more tethered to the anti-apartheid struggles. Drawing on northern traditions of Marxism and sociology, South African sociologists pioneered their own brand of sociology - materialist theories of racism, new approaches to class formation, innovative analysis of articulation of modes of production and a novel industrial sociology and theory of social movements. These new sociologies did not arise from the rejection of 'northern' sociology, but rather adapted it to a new national context. Lewis Coser's (1964) and Ralph Dahrendorf's (1959) institutional theory of class conflict were deployed by Eddie Webster to call for the recognition of African trade unions. Harold Wolpe (1972) took Marxist theories of the articulation of modes of production to demonstrate the specificity of the political economy of racial apartheid and its roots in the reproduction of cheap labor power. Charles Van Onselen (1982) and others were inspired by English social historian, Edward Thompson, to develop a new social history of South Africa. Thus, far from being 'counterhegemonic' (Kiem, 2011) the Sociology of Work Programme (SWOP) at the University of Witwatersrand drew on northern sociology, but developed it in novel directions. Original and important though it was, born in South Africa it had difficulty finding its way northwards, let alone challenging the hegemony of northern sociology. It was rather conducting itself on the terrain of northern sociology.

Latin America has had its own sociological traditions that came to global attention with the advance of dependency theory, formulated in opposition to modernization theory - the teleology of development was replaced by the teleology of underdevelopment, in Andre Gunder Frank's (1969) felicitous phrase, the 'development of underdevelopment'. Those, such as Fernando Henrique Cardoso and Enzo Faletto (1979), who found this reverse teleology too pessimistic, adopted anti-teleological approaches that gave space to state-sponsored 'dependent development'. In the era of dictatorship, new 
theories of bureaucratic authoritarianism were born, followed by theories of democratic transition, often linked to parallel changes in the former Soviet Union and Eastern Europe. Today Latin American sociology shows a burgeoning interest in movements to deepen democracy as a reaction to the strictures of structural adjustment. As in Asia and Africa so within Latin America there is a hierarchy of influence among national sociologies, dominated by Brazil whose federal universities are, relatively speaking, lavishly funded. While Latin American sociology has had more influence than African, its presence in northern theory is nonetheless still weak and largely confined to subdisciplines development, political sociology, social movements - or at the fringes of social theory. Still, the contestation of dominant sociologies is still within the framework of a singular global field of sociology, it is contestation on the terrain of hegemony rather than against hegemony.

In the Soviet Union and its satellites sociology was considered a bourgeois science and for many years it was banned. With the eclipse of Stalinism and the political thaw that followed in its wake, sociology took on a precarious existence as an ideological instrument of the party-state. This, in turn, generated its own dissident sociology, especially in countries such as Hungary and Poland where there was more political space to cultivate alternative sociologies, often influenced by US and European sociology. Here we find original theories of stratification and even class analysis, reflections on intellectuals and their place in history, revisionist views of Marxism that appealed to Marx's proscribed early writings (widely read in the West), a sociology of economic planning and its articulation with markets. The most significant and original theorization of state socialism, penned by Gyorgy Konrad and Ivan Szelenyi (1979), fused a Marxian class analysis with a Weberian analysis of rationalization to understand the rise of intellectuals on the road to class power. Today, these traditions, once forged in opposition to party orthodoxy and Marxism-Leninism, are now largely forgotten as these countries struggle with the fall out of neoliberalism. One is hard pressed to find authentic national traditions as sociologists scramble to adapt and adopt northern theory.

In China sociology followed an even more precarious existence than in the Soviet Union, only really developing in the post-Mao period of the 1980s. In the universities sociology has been pioneered by US trained PhDs while state-sponsored sociology prevails in the Academy of Sciences. The party-state keeps a keen watch on the critical potential of sociology, although niches of such sociology do exist in protected places. Taiwan offers a curious exception, reflecting its hazardous position between China and the USA, trying to maintain its autonomy. A younger generation of sociologists were active in the democracy movement of the 1980 s, contesting the authoritarian rule of the KMT, and this continues to mark Taiwanese sociology. Many were trained in the USA, but drew on strands of a more critical sociology, including feminism and Marxism.

As I have indicated US sociology is no exception to the salience of national sociology, although it has been most guilty of claiming universality for what is a quite peculiar society. Beginning with its theological roots in the 19th century it became institutionalized with the so-called Chicago School and in other universities, such as Columbia. Subsequently, after the Second World War it became consolidated around structural functionalism and increasingly sophisticated quantitative research, only to be subsequently radicalized under the influence of social movements. Most recently, there has 
been a return to a more conservative vision with the resurrection of cultural and neoinstitutional sociology. Like any national field of sociology it is not beyond the influence of other national sociologies, especially European social theory. Structural functionalism was originally built on Parsons' interpretation of Weber, Durkheim, Pareto, and Marshall, while the Marxist countermovement drew on French structuralism, German critical theory, and English empiricism. Today, French social theory of Bourdieu in particular, but also of Boltanski and Latour, has the upper hand.

In every case the influence is shaped by the context of reception. The import of US sociology is rarely a straightforward imposition or superimposition, but a deployment by actors operating in a national field - national fields that are not homogeneous but themselves a terrain of struggle. In their internal struggles they often appeal for legitimacy to opposing strands within US sociology and French sociology as well as sediments of national traditions themselves shaped by and in reaction to northern sociologies.

\section{Governmentality: Rationalizing the Global Field of Sociology}

Ever since the Second World War US sociology has dominated world sociology whether we measure this in terms of the number of PhDs, investment in research, control of prestigious journals, membership in national associations. The USA concentrated enormous resources in its expansive system of higher education, which was itself heavily stratified. The conditions of work at US research universities are still the envy of the world. With the concentration of material resources came symbolic domination. No matter how critical foreign sociologists may be of US sociology, they rarely turn down a position or a fellowship in US universities. Domination and desire work hand in hand.

Scholars rarely come to the USA to study the USA, but to deploy their symbolic capital in studies of their homeland and to return there as consecrated academics and experts or, for the most successful, to find employment in the USA. When US scholars, on the other hand, visit other countries it is more likely that they go to conduct research. Moreover, they generally do so through US frames often inattentive to local frames. Even when they deploy critical perspectives, such as world systems theory, they deepen the domination of US sociology, by demonstrating its heterogeneity as a field.

That symbolic and material domination is now being consolidated as a form of governmentality that rationalizes the hierarchical articulation of national fields, merging national fields into the global field. As universities across the world are being forced to finance themselves, so they have cut costs through the replacement of permanent tenured faculty by adjuncts and temporary lecturers, by moving to distance learning, by outsourcing support services. At the same time, they seek new sources of revenue - research grants, student fees especially from high-paying foreign students, patents, corporate sponsorship, and even real estate investment. In transforming the university into a profit center, the administrative apparatus expands and develops its own corporate structure. The search for funding becomes a competitive struggle in branding that takes place through ranking systems - national, regional, and global.

The Chinese initiated the global ranking system with the Shanghai Jiao Tong system that was designed to evaluate their own universities against what they considered to be the 
best in the world, namely the US research university headed by the Ivy League universities. So they used such criteria as the number of Nobel Prize and Medal Winners, publications in major journals with high impact factors, and research funding. Once the ranking system was established other countries adopted it to evaluate their own universities, creating a hierarchy of world class universities. States desperately try to get their universities into the top 500 - a list that is dominated by US universities. According to the Shanghai ranking, in 201416 of the top 20, 32 of the top 50, and 52 of the top 100 were US universities. Resenting the US orientation of the Shanghai system, other countries introduced their own ranking systems, such as the Times Higher Education system emanating from the UK, based on different weighted factors, but the effect is the same: to force national fields into alignment with northern science, and particularly US science.

In sociology the result has been to exacerbate divisions within national fields of sociology. On the one hand, the elite universities intensify the pressure on their faculty to orient scholarship to the global field of sociology, and most importantly to publish in so-called 'international' journals that are usually US or European journals, journals that cannot escape a national or regional outlook. In many countries academics are given financial rewards for publishing in 'high impact' northern journals. This happens not only in universities of the Global South but also in European universities where academics are increasingly expected to publish in English (which is the medium of high impact journals) and even teach in English (to recruit foreign students). Journal editors are also pressured into raising their 'impact factor', which means publishing articles in English, recruiting big names, and so forth.

All this has consequences for the conduct of research - incentivizing methods and theories that are recognized as legitimate among the reviewers of US journals. Sociologists are, therefore, pulled away from the problems, issues, frames of national relevance, pulled away from national publics in favor of professional peers in other countries, most importantly metropolitan countries.

Relatively few academics can actually aspire to become part of this global field, and in the South they are often the ones who have had the benefit of training in the North, those who travel in global circuits. The majority of academics find themselves relegated to ever-more degraded institutions, starved of resources, barely able to eke out an existence - poorly paid and over-worked, taking on multiple jobs - a rising precariat within the academy. The national field is increasingly polarized between the minority, endowed with resources and good working conditions, and the majority whose main function is to service massive numbers of students. The national field is Balkanized as elites are absorbed into a global field, itself promoted by nation states intent on having a symbolic foot in the door of global science.

From above the hierarchical order that defines the global field appears to be based on 'distinction', a superiority born of supposed gift and talent - so that domination becomes a form of symbolic power that is misrecognized as natural and pre-ordained. The sociology elites have no doubt about their claim to distinction, being recipients of awards, recognition, publications, invited addresses that confirm their entitlement to superiority. In their eyes protest from below through calls for 'national sociologies', 'indigenous sociology', 'postcolonial' theory, or 'southern epistemologies' are the irrational voices of populism or relativism - political strategies of the weak of mind, bereft of discipline. If 
the challengers garner support from a few dissident voices, that only convinces the dominant of their distinction.

From below, the hierarchical order appears as an expression of arbitrary power based on the concentration of material and symbolic resources - the sociology of the dominant is presented as universal and thus imposed on the dominant as the only legitimate sociology. Modernization theory, for example, understood underdevelopment in Africa as a function of an inhospitable culture based on primordial attachments to tribe and kinship, that is a failure to replicate presumptively western rationality, thereby ignoring the economic constraints of world capitalism and the legacy of colonialism.

Given the realistic options they face, southern sociologists are tempted to endorse embrace or comply with - the 'distinction' of their northern colleagues, acting as ambassadors of the North, seeking to impose its standards and its frames on their brethren as the only sociology. They may translate the books of northern sociologists, invite them to visit their countries as celebrities, and in return receive opportunities for collaboration and residential fellowships. For those with the social connections and language skills, this is an established career trajectory, which is only intensified by instrumentalities - incentives and strategies - that merge national fields into the global field of sociology.

\section{Global Sociology Needs Public Sociology}

In principle, there are two ways of contesting this globalization of the sociological field. A global sociology can either work within the constraints of the hegemonic order or it can work against that order, seeking to constitute an alternative hegemony. In this era a counter-hegemonic strategy has great difficulty in surviving, and pursuits in this direction are likely to doom its advocates to irrelevance.

But what does it mean to struggle on the terrain of hegemony? It means taking sociology that was developed in the North, and infusing it with new elements, reshaping it for different southern contexts. We have already noted the way Eddie Webster and his colleagues deployed or reconstructed US sociology to suit apartheid and post-apartheid South Africa. More recently, Karl Von Holdt (Burawoy and Von Holdt, 2012) has engaged the relevance of the writings of Bourdieu for South Africa. On the face of it Bourdieu's focus on symbolic violence and classification struggles is supremely at odds with the physical violence and class struggles that pervade South African society, but Von Holdt shows the importance of thinking about the relationship between symbolic and physical violence, classification struggles, and class struggles. Or to take another example, Von Holdt took Bourdieu's idea of habitus but rather than emphasizing the way it produces conformity, he shows how it produces defiance - a sociology from Bourdieu against Bourdieu. In modifying Bourdieu he also casts new light on South Africa.

Rather than the development of southern theory, this strategy is akin to Edward Said's (1983) traveling theory that takes on different meaning in different contexts. Theory often does not have a southern or northern origin but circulates between the two. Frantz Fanon himself deployed existentialism, Marxism, and psychoanalysis first to understand immigrant responses to racism in France and then to understand colonialism and anticolonialism in Algeria. His theories were then redeployed by radical African American groups in the United States in ways that were never anticipated or intended by Fanon himself. This example subverts the distinction between northern and southern theory. 
The contest on the terrain that defines global sociology does not invert power relations between North and South, but re-articulates them, by giving place and voice to the South.

A sociology in and from the South cannot compete with the material resources of the leading northern universities, and so it has to seek an alternative power base. The strength of the sociology of Webster, Von Holdt, Cock, and others lies in the institution they constructed - Society, Work and Development Institute, otherwise known as SWOP, at the University of Witwatersrand - an institute with tentacles in civil society (trade unions, social movements, and more guardedly the post-apartheid state) that has also trained generations of sociologists for the new South Africa. It is one of many such institutes, usually interdisciplinary, including Focus on the Global South (Thailand), Center for Studies in the Social Sciences (Calcutta), Cenedic (Sao Paulo), CREA (Barcelona), De Justicia (Bogota), Center for Independent Social Research (St Petersburg). The strength of such sociologies cannot come from their material wealth but from their relational wealth, the rich ties that they plant within society, generating a sociology for the South that is nonetheless tied to sociologies from elsewhere. Such institutes will have to defend their embedded autonomy - embedded in but autonomous from society - against pressures of commodification and rationalization (Burawoy, 2014).

A paradigmatic forerunner of such challenges to dominant perspectives can be seen as WEB Du Bois' Sociology Laboratory in Atlanta. Aldon Morris (2015) documents the way $\mathrm{Du}$ Bois was able to build up a research program that challenged the reigning Chicago sociology, by working with what Morris calls 'liberation' capital, substituting political relations with communities of activists for research funding he was systematically denied. This embedded autonomy of public sociology allowed him and his AfricanAmerican colleagues to create and sustain a distinctive sociology that was more scientific than Chicago sociology - that still retained strong influences of a speculative philosophy of history - and was also more critical of the status quo.

Today, to contest the hegemony of heavily funded and institutionally backed 'universalistic' sociologies that are unmoored and fly above the ground it is necessary to go local, to develop a public sociology that works with and against dominant sociologies of the North. But a public sociology that is not simply accessible but accountable to publics. Sari Hanafi (2011) has memorably written, 'Publish globally and perish locally vs publish locally and perish globally.' The point, however, is to somehow do both to build ties to the local that sustains a critical engagement with the global. And this will be important not just for subaltern sociologies, but for the survival of sociology of and in the North, if it is to retain its relevance in an ever more globally connected world.

While sociologists of the South have always had to cope with the limitations of northern sociologies, the latter can no longer survive as though in splendid isolation since now the very worlds they have ignored have returned to haunt them. The comprehension of violence in the metropolis, for example, requires understanding the creation of a nexus of marginalization and uprooting that connects disenfranchised groups across national boundaries - the consequences of coloniality on a world scale.

\section{The Promise of Sociology}

If global sociology is riven by the same hierarchies it analyses, is there any reason to partake in its reconstruction? Is it worth working from within a global hegemony, albeit 
one that recognizes the importance and vitality of multiple sociologies organized in a complex pattern of domination, but a pattern that can be contested and rearticulated?

Domination notwithstanding, is there a common project that defines the unity of sociology, that unites all sociologists in and through their struggles and despite their struggles. Is there a taken-for-granted commitment that can make sociology a global vocation? What is the illusio of the global field that fuels the moral commitments of all sociologists? What binds us to sociology at all, never mind, global sociology?

Believing that sociology's best days are gone - its halcyon years of the second half of the 20th century - luminaries, as different as Immanuel Wallerstein and Alain Touraine, call for dissolving sociology into a broad social science. To be sure, sociology has seen better times in many countries of the Global South as well as in the North. In many locales it is being amalgamated with other disciplines such as anthropology, intensifying migration into professional schools such as social work and business, or joining multidisciplines such as cultural studies. Curiously, however, national and even global associations have never been stronger. To cry farewell to sociology is not only premature, but also dangerous.

To dissolve sociology into a broad social science would accede to the domination of economics and its ever-closer conspirator, political science at the very time its values and commitments are most needed. It would be collective suicide to abandon sociology's distinctive heritage as the critic of market fundamentalism and state authoritarianism. Starting with Marx, Weber, and Durkheim moving on to Simmel, Parsons, and Habermas, and thence to Wallerstein, Bourdieu, and Bauman, to feminism, critical race theory, queer theory, and postmodernism and traversing the world to theories of coloniality and postcolonialism - one thing all these strands of sociology have in common is the critique of restricted visions of social action, utilitarianism, and rational choice theory. Holding on to this critique is all the more important in a time of the ascendancy of market fundamentalism, when the very standpoint of sociology, namely the autonomy if not the existence of civil society as a bulwark against state and market, is in retreat the world over. Sociology's weakness as public discourse is paradoxically a sign of its strength as a critical tool in an intellectual world that is fast losing its critical faculties.

Thus, global sociology is a terrain of struggle internally but also externally, against the domination of economics and political science. In this struggle we have allies in other disciplines such as human geography, anthropology as well as redoubtable dissidents within the fields of political science and economics. There is, therefore, a common project that unites sociologists across both national and disciplinary boundaries even as there is a productive conflict over how exactly that project should be defined, and whose voices shall be heard.

\section{Acknowledgements}

I would like to acknowledge the critical commentary of two anonymous reviewers which helped me improve the article.

\section{Funding}

This research received no specific grant from any funding agency in the public, commercial, or not-for-profit sectors. 


\section{References}

Bhambra G (2014) Connected Sociologies. London: Bloomsbury Academic.

Breman J (2013) A bogus concept. New Left Review 84: 130-138.

Burawoy M (ed.) (2014) Precarious Engagements: Combat in the Realm of Public Sociology. Current Sociology Monograph 62(2).

Burawoy M and Von Holdt K (2012) Conversations with Bourdieu. Johannesburg: University of Witwatersrand Press.

Cardoso FH and Faletto E (1979) Dependency and Development in Latin America. Berkeley, CA: University of California Press.

Chakrabarty D (2000) Provincializing Europe. Princeton, NJ: Princeton University Press.

Chatterjee P (1986) Nationalist Thought and the Colonial World. New Delhi: Oxford University Press.

Comaroff J and Comaroff JL (2012) Theory from the South: Or, How Euro-America is Evolving toward Africa. Boulder, CO: Paradigm Publishers.

Connell R (2007) Southern Theory: The Global Dynamics of Knowledge in Social Science. Cambridge: Polity.

Coser L (1964) The Functions of Social Conflict. New York: Free Press.

Dahrendorf R (1959) Class and Class Conflict in Industrial Society. Stanford, CA: Stanford University Press.

Fanon F (1963 [1961]) The Wretched of the Earth. New York: Grove Press.

Frank AG (1969) Latin America: Underdevelopment or Revolution. New York: Monthly Review Press.

Genov N (ed.) (1989) National Traditions in Sociology. London: SAGE.

Guha R (1983) Elementary Aspects of Peasant Insurgency in Colonial India. New Delhi: Oxford University Press.

Hanafi S (2011) University systems in the Arab East: Publish globally and perish locally vs publish locally and perish globally. Current Sociology 59(3): 291-309.

Kiem W (2011) Counterhegemonic currents and internationalization of sociology. International Sociology 26(1): 123-145.

Konrad G and Szelenyi I (1979) The Intellectuals on the Road to Class Power. New York: Harcourt Brace Jovanovich.

Morris A (2015) Scholar Denied: W.E.B. Du Bois and the Birth of Modern Sociology. Berkeley, CA: University of California Press.

Patel S (ed.) (2010) The ISA Handbook of Diverse Sociological Traditions. London: SAGE.

Quijano A (2000) Coloniality of power and Eurocentrism in Latin America. International Sociology 15(2): 215-232.

Said E (1983) Traveling theory. In: The World, The Text, and The Critic. Cambridge, MA: Harvard University Press, 226-247.

Sztompka P (2011) Another sociological utopia. Contemporary Sociology 40(4): 388-396.

Van Onselen C (1982) Studies in the Social and Economic History of Witwatersrand, 1886-1914. Books I and II. London: Longman.

Wolpe H (1972) Capitalism and cheap labour-power in South Africa: From segregation to apartheid. Economy and Society 1(4): 425-456.

Michael Burawoy teaches sociology at the University of California, Berkeley and is an Associate of the Society, Work and Development Institute at the University of Witwatersrand, South Africa.

Date submitted September 2015

Date accepted December 2015 